\title{
Editorial
}

\section{Eberhard F. Mammen Award Announcements}

Emmanuel J. Favaloro, PhD, FFSc (RCPA) ${ }^{1}$

${ }^{1}$ Department of Haematology, Institute of Clinical Pathology and Medical Research (ICPMR), Westmead Hospital, Westmead, New South Wales, Australia

Address for correspondence Emmanuel J. Favaloro, PhD, FFSC (RCPA), Department of Haematology, Institute of Clinical Pathology and Medical Research (ICPMR), Westmead Hospital, Westmead, New South Wales 2145, Semin Thromb Hemost 2013;39:972. Australia (e-mail: emmanuel.favaloro@swahs.health.nsw.gov.au).

\section{ERRATUM}

The publisher regrets an inadvertent error in the name of Dr. Cristiano Fava, one of the winners of 2013 Most Popular Eberhard F. Mammen Awards, in the above editorial in Seminars in Thrombosis \& Hemostasis, Volume 39, Number 6, p. 572, doi: 10.1055/s-00331349792. The name was incorrectly published as Cristino Fava. The correct listing of the name is Cristiano Fava as mentioned above. 